\title{
Introduction: The New American Studies
}

\section{From Myth to Rhetorics}

The essays in this collection represent the work of a new generation within American studies, and they define a new idea of what it might mean to do American studies and how one would go about doing it. They also represent the rich diversity of explanations and materials in the study of American culture. Films and photographs, Supreme Court decisions and industrial manuals, educational and domestic theory, the popular culture of Horatio Alger and the standard genres of domestic fiction: a culture in its full institutional and individual variety is here in play. At the same time, because these essays have been drawn from the journal Representations they do not reach out to every recent style or topic of analysis. To take one limitation, Whitman is the only poet who plays a central part here.

One way to characterize this new generation of American studies would be to say that interest has passed from myth to rhetorics. Myth in this perhaps too simple formula is always singular, rhetorics always plural. Myth is a fixed, satisfying, and stable story used again and again to normalize our account of social life. By means of myth novelty is tamed by being seen as the repetition or, at most, the variation, of a known and valued pattern. Even where actual historical situations are found to fall short of myth or to lie in its aftermath, the myth tames the variety of historical experience, giving it familiarity while using it to reaffirm the culture's long-standing interpretation of itself.

Rhetoric, on the other hand, is a tactic within the open questions of culture. It reveals interests and exclusions. To look at rhetorics is to look at the action potential of language and images, not just their power or contrivance to move an audience but also the location of words, formulas, images, and ideological units of meaning within politics. Rhetoric is the place where language is engaged in cultural work, and such work can be done on, with, or in spite of one or another social group. Rhetorics are plural because they are part of what is uncertain or potential in culture. They are the servants of one or another politics of experience. Where there is nothing openly contested, no cultural work to be done, we do not find the simplification into one and only one rhetoric. Instead we find the absence of the particular inflammation and repetition that rhetoric always marks. We find not rhetoric, but the ceremonial contentment of myth. Rhetorics are also distinct from ideology. In the term ideology we rightly hear a combination of cal- 
culation, cynicism about social truth, a schoolmaster's relation to his pupils, indoctrination, and propaganda. Whether as reality or hope, ideology implies that the legitimacy of authority depends in part on a monopoly on representation, and this is exactly the condition in which rhetorics become irrelevant.

To understand what a move from myth to rhetorics might involve it is useful first to look at two things: how the claim of a unitary myth worked and was used during the period we might call the transfer of literature to the American university; and the counter element to unitary myths within American studies, the force of regionalism.

\section{Myths and the University}

The new field of American studies came to maturity in the years just before and after the Second World War. Its description of American experience had as its audience both Americans themselves and, even more important, a wider world in which American culture had begun to work as a kind of world culture. Both Europeans and Americans were asked to consider in mythic terms a prior state of American experience, one whose essence and importance lay in the fact that it no longer existed but had generated the cultural heart of American experience. But to this prior culture of Puritan mission, frontier, wilderness, garden, and innocence contemporary Americans were just as much outsiders as Europeans or Asians were.

In this charged pre- and postwar atmosphere of cultural victory and cultural defeat, Americanists undertook the search for a central myth of America. Such key works as Henry Nash Smith's Virgin Land, Leo Marx's Machine in the Garden, R. W. B. Lewis's American Adam, or Richard Slotkin's Regeneration through Violence encouraged a study of literature, everyday culture, and history around a shared mythic content that captured American uniqueness and national identity. American studies as an academic field in its first generation took this myth of America to be its central topic and its method for linking the classics of American poetry, fiction, and painting to the everyday culture of images, newspapers, sermons, political rhetoric, and especially to popular fiction and verse. Here the western and the sermon met.

The first of these all-encompassing myths of America had, in fact, been defined half a century earlier. This was Frederic Jackson Turner's frontier myth, a hypothesis, as Turner called it, but ultimately a story rather than a scientific speculation, a story whose appeal lay in the curious fact that it described just those social features lost forever in the official closing of the American frontier noted in the census of 1890. Although Turner's great myth appeared before what we might call the capture of American culture by the universities, an event that took place in the 1930s and 1940s, his strategy of discovering one fundamental fact or 
myth that explained the identity of America as a nation set the stage for the mythic cast of the first generation of academic study of American culture. After the frontier myth, the second most important global explanation was the myth of the Puritans: their mission, the unique importance of intellectuals and ideology in Puritan experience, the primacy of New England's religious forms for American politics, and the residue of Puritan energy, now invested in commerce and self-cultivation, that remained as a permanent trace within national character. If the frontier myth was a myth of the West, the Puritan myth was a myth of New England culture, asserting its right to an ongoing leadership in national life. Where the western myth was democratic, based on the experience of immigration and self-reliance, the New England myth was ultimately a myth of the importance of intellectuals and, with them, of the crucial role played by writing and by those who provide ideology, self-description, and history, of the importance, finally, of preachers and their descendents, the intellectuals of the nineteenth century and the university professors of the twentieth.

In spite of the built-in resistance of American literature and its awkward wildness, no cultural fact is more important over the past fifty years than the wholesale movement of every component of American literary life, past, present, and future, into the universities. American studies and American literature everywhere arrived at legitimacy. American poets were signed up as writers in residence. Men and women of letters, following Philip Rahv and Irving Howe, became professors, trading in their general audience of educated adults for a classroom full of students eighteen to twenty-five years old, and for a secondary audience of their professional colleagues who had now become the main readers of their opinions. Little magazines became subsidized by colleges, where they too were now "in residence," and they found their primary guaranteed sales to the periodical rooms of university libraries. The paperback revolution of the fifties and sixties that promised at first to democratize culture by making inexpensive editions widely available ended up filling bookstores with texts instead of books, texts designed for adoption as required reading in courses.

The high-level professional work on this new subject of American literature has been shaped to a remarkable degree by this residence of culture within the academic world. The university and the professor think, as they must, in terms of courses, that is, in terms of a coherent set of books or themes that fit into the fifteen-week semester. Such distinguished critical studies as F.O. Matthiesson's American Renaissance, Leo Marx's The Machine in the Garden, or Henry Nash Smith's Virgin Land set out the past as a set of model courses. The great interest in myths of the frontier, the machine, the Puritan errand into the wilderness, American violence, or American individualism served to give shape to the academic year in an ordered, consecutive, thematic way with developments and oppositions. The problem of the American romance as opposed to the novel, or the description of so arbitrary a period of history as what is known as the Gilded Age, redesigned 
the past to fit the intellectual needs and temporal rhythms of the newly professionalized study of the past.

The most common theme of the first generation of Americanists was what could be called the disappointment of myth by fact, the failure of reality to live up to the ways in which it had been imagined. America was first mythologized as the second Eden, its purpose linked to the Puritan mission, or was pictured as a frontier or free space for the unbounded individual, but then, in each case, the myth was betrayed by fact. The promise was unkept, the purity of what had been imagined grew stained over time. American reality, by means of the apparatus of myth, always took on the look of a fallen state. The frontier had been closed. The high moral purpose of the Puritans had given way to commerce and commercial purpose. The innocence had blood on its hands. What was there had the look of heavily discounted possibility. What might have been had been disappointed in the act of making.

Significantly, one of the master texts of this generation was Henry James's The Ambassadors, perhaps from an academic point of view the most perfect book ever written by an American. James's hero, Strether, creates a myth of Paris, a myth of his charge, Chad, a myth of Chad's relation to Mme de Vionnet. Each myth is betrayed by fact, stained by the complexity of the real world. An entire academic generation saw its own love of criticism, observation, nuance, disappointment, myth, and defeat in James's novel.

As the great academic popularity of James's novel made clear, if there has been one history lovingly traced by intellectuals over the past fifty years it has been the history of intellectuals themselves. Beginning with the work of Perry Miller in the late thirties, the explanation of America as a long history of Puritan hope and decline resulted from the fact that academic intellectuals, looking into the past to find not necessarily its chief actors but precisely those congenial figures whose analytic and critical stance most resembled their own, discovered in the Puritan writers what was for them the most intelligible feature of the past, the one mirror most filled with familiar features. They too were intellectuals, engaged in holding up a mirror of admonition or exhortation to their society. In theocratic New England they found embodied the secret self-image of all intellectual cultures, a society in which the critics and intellectuals were not marginal, but actually in power.

The Puritan intellectuals had their successors in the radical critics of society from the mid-nineteenth century to the 1950s and 1960s. In the 1930s utopian intellectuals of the left found in the radical Puritans of three hundred years earlier their own model for the role and the hoped-for importance of the intellectual in politics and society. However marginal intellectuals have actually been within American culture, the study of America has reclaimed them.

Useful though the history of intellectuals as written by their own aspiring descendents might be, it is, in the end, a rather timid look into the most friendly 
and probably most unrepresentative district of the American past. The actors in the history of exploration and settlement, enterprise and invention, city building, money, and speculation in America, in the tangled history of black and white, Native American and settler, and political and personal rebellion have been the protagonists of the American story, even if, unlike the intellectuals, they have seldom been their own best historians.

Myth creates a fault line between what ought to have taken place and what did. It permits ideas and facts to criticize each other. Like individual rebellion or reform movements, myths embody what Henry Adams in his Autobiography called "the spirit of resistance." The appetite for resistance led Lionel Trilling to propose that all culture was basically adversarial in the modern period, at war with the commonplace or everyday social energies and beliefs. In European culture of the nineteenth century this adversarial position reflected the failure of self-belief among the emerging middle classes that had at last achieved political and cultural power equivalent to their economic importance. But in America the source was quite different. It lay in a utopian or even moral radicalism combined with or concealing the resentment of artists and intellectuals at their rather small voice in a national life dominated by business and politics.

The belief in this spiritual radicalism led to a focus on those writers like Melville who said their "No! In Thunder." Melville's Pierre or Bartleby, Hawthorne's Hester Prynne, Thoreau at Walden Pond or spending a night in jail, Henry James withdrawn to England because American reality was not thick enough: these defiant, adversarial figures and the meaning of the challenging distance they created in standing out by standing against their world are what the study of the tension between fact and all that resisted fact brought to the center. One of the aims of Sacvan Bercovitch's essay on Hawthorne in this volume is to dissolve the hold of such complacent descriptions of the adversarial. Within American studies the study of America had become the study of dissent. The rebels and dissidents came to the front as the leading patriots. It was the era of Thoreau, Henry Adams, and Bartleby, not of Emerson and Whitman. The search for central myths, myths already closed off, like the frontier at the moment it was first described as the single most vital experience for American identity, was inseparable from the study of resistance within culture, whether in the gothic style of Melville's Pierre, the reflective emigré style of James's Ambassadors, or the selfironic style of Henry Adams's Education.

By an accident of timing, American literature arrived in the university at a highly politicized moment. Its arrival coincided with the polarization between right and left or, in European terms, between fascism and communism, in the period between the two world wars. The study of resistance was attractive in part because both the conservative right and the liberal left had each rejected one key feature of what had been a synthesis in the most vital parts of nineteenth-century American culture. The right was hostile to democracy; the left to capitalism. Both 
shared a distrust of the optimism, energy, confidence, and what might be called the surprisingly guiltless relation that figures like Emerson, Whitman, Cooper, or Parkman had to their own past. The lack of apology or contrition, the robust confidence in the right to be where and as they were in spite of slavery, Indian massacres, the failures of national politics to be dignified or even honest, the violence of the West, the polyglot hustle of the new cities-such guiltless selfregard seemed shallow to a left and to a right equally convinced of the nightmare of history. A whole new meaning of the term innocence had to be invented to make it seem that only some youthful unawareness of evil could explain the pride or health of Twain, Whitman, William James, or Emerson.

That the very greatest figures of American literature were not oppositional figures seemed almost beyond belief. But it was a fact. There is no margin of frictional energy that accounts for Emily Dickinson or Dreiser or Faulkner. Whitman and Emerson continue to embarrass by their failure to have seen through democracy and capitalism, or rather by their having imagined themselves to have seen into the philosophic and temperamental depths of those two systems and to have found them both profound and humane, exhilarating and enduring.

\section{Regionalism and Central Culture}

Alongside the search for grand unifying myths, with their inevitable narrative of a fall into imperfection and disappointment, a second element shared the stage. This second element was the claim of pluralism within American culture. This diversity, which resists the single shelter of myth or ideology, has again and again risen to dominance in what we might call the episodes of regionalism in American cultural history.

Cultural life in America swings like a pendulum between a diversity of sectional voices and an ever-new project of unity, between the representation of the nation as made up of weakly joined districts and the representation of a central national order. Some 150 years ago the then strongly sectional culture was split along geographical lines: the New England mind, the Southern way of life, the West of the pioneer with his energy and his violence. Each section had its own voices and themes, its own philosophies and religions, its unique spirit and humor. A new common identity was only rebuilt out of these regionalisms by the Civil War, by the mythic figure of Lincoln, by the railroads and telegraph that reconquered a geography grown too large for the earlier Federal unity of Washington and Jefferson, and by the elaboration of an American way of life made up of Singer sewing machines, Coca-Cola, Remington rifles, and Ford Model T's-a common way of life created around democratically available mass-produced goods rather than by the right to vote or own property. 
Each swing to regionalism splits the country along different fault lines and each rewon unity involves not a return to a lost identity, but a new plane of association. In early twentieth-century America a new regionalism that was not geographic but ethnic appeared as a result of massive immigration. The local "color" was not that of climates and regions, but of hyphenated Americans: JewishAmericans, Italian-Americans, Irish-Americans, Wasps and Chinese-Americans, Poles, Swedes, and Russians. This was a regionalism of languages, folk customs, humor, music, and beliefs set over against the pull of what came to be called Americanization.

In this case it was not the railroads and the everyday objects of a thriving economy that created the unifying force. To this ethnic regionalism was opposed the core culture of the system of public education and the incentive of economic advancement always purchased at the price of a surrendered culture, most obviously by the requirement of the schools and the business world that the English language be used. A third unifying force was mobility itself. Only by remaining within a ghetto, the ghetto of arrival, could the coherence of language, ways of life, religion, and, most important, marriage within the ethnic group be preserved. To move even once was to enter the general American condition.

Again in this case, the two world wars and the common democratic experience of the army worked, as the Civil War or the Revolutionary War had earlier, to fuse a new identity that superseded the ethnic diversity of the late nineteenth and early twentieth centuries. The pots in which the melting actually occurred were the schoolroom, the new offices of the business world, and the fields of battle. Unity within American culture has always been a postwar unity, whether federalist after the Revolution, capitalist after the Civil War, or contemporary American after, and resulting from, the two world wars that ended in 1945.

In recent years a further episode of regionalism has begun. The regionalism of the past decades has been neither geographical nor ethnic. It comes on the heels of the generation that elaborated the myth of America in the shadow and aftermath of World War II. The regionalism of our own times is a regionalism of gender and race. The civil rights movement after 1954 had as a cultural corollary the debate over black identity in America. The women's movement that followed, just as the nineteenth-century suffrage movement had followed and drawn its vocabulary from abolitionism, set the model for the denial of what came to be called "essentialism," the claim to an overriding common identity. Later gay and lesbian identity movements, along with ethnic identities now conceived not on the model of the earlier hyphenated identities, but on the more radical model of black or female identity, reopened the full spectrum of regionalized culture. Native American, Chicano, gay, black, lesbian, female: a third episode of regionalism once again set out its claims, in this case against a central technological culture made up of the new media, television and film, and also of the older forces of education and mass representation. The model that black or female identity 
set in place for regionalism was refractory in a novel way because these regionalas opposed to universal-models were the first within American experience that would never be altered by either mobility or the succession of generations in a culture where intermarriage was common. Earlier geographic or ethnic identities were episodic in that the very mechanisms of the culture itself would erase them over time. To be black or female was an unnegotiable identity, and insofar as other groups, including ethnic groups, took over the black model, they chose to see their own regional identity, their identity at birth, as final.

In American universities, the newly founded departments of American studies of the 1930s, 1940s, and 1950s, found themselves in the 1960s and 1970s quickly regionalized into departments of black or Afro-American studies, Jewish studies, women's studies, Native American studies, Chicano and Asian-American studies, and in some cases, gay studies. One aspect of these new identity claims was an aggressive unmasking of the myths of the previous generation, among other things as an overwhelmingly white male myth of America. The pastoral, the Western, the Puritan mission, the frontier experience of individualism, selfreliance, and democratic values: all had at their center white male actors with various supporting casts.

The new American studies has grown up alongside but also as an alternative or aftermath to this regionalism that tore apart the various unifying and singular myths of America. The key limitations to this new regionalism, as well as of all earlier regionalisms, were its need to define itself and its ability to thrive only within a highly politicized atmosphere. Regionalism is always, in America, part of a civil war within representation. It is seldom or never a matter of tolerance, the blooming of a thousand, or even of three, flowers. In the regionalism of the past decades, identity is formed by opposition: black/white, female/male, Native American/settler, gay/heterosexual. Because of this opposition, identity is located above all in the sphere of politics, that is, in the sphere of felt opposition, of movements, laws, demands, negotiations over representation, and, in the university, in struggle over curriculum and requirements.

The new American studies has stood outside this regionalism by locating a set of underlying but permanently open national facts around which all identities are shaped and with which the many rhetorics of our culture are engaged. Among these permanently open, that is, never won nor lost, national facts are democratic culture and its demands; the culture of freedom that permits conditions of dominance, whether economic, sexual, or cultural, and has permitted even permutations of slavery as one aspect of the nature of freedom itself; the creation of a national life that is economic rather than religious or, in the anthropological sense, cultural. This troubled utopian core of enterprise, freedom, and democratic culture baffled by the preexisting social facts while never surrendering to them is essential to the cultural analyses in the essays of this book. 


\section{The Civil War within Representation}

One consequence of the new American studies has been to rethink the traditional concept of the American Renaissance, replacing it with the new category of a literature located within the Civil War over slavery and driven by the particular concepts of freedom and independence, politics and compromise, that the Civil War period, with its preparation and aftermath, froze into place. Recent European historical work, particularly Reinhart Koselleck's essays on the concept of revolution in his book Future's Past, has focused on the part played by civil wars in the grounding and contesting of national identity in the three hundred years between the European Thirty Years War and the English civil war of the seventeenth century and the end of the general European civil war of 1914-1945. Like the U.S. Civil War and the French and Russian revolutions with their phases of civil war, all such wars put at risk the very existence of the society itself in the name of uncompromisable values. Periods of civil war are periods without ideology because two or more rhetorics of self-representation, national purpose, and historical genealogy are in wide enough circulation to elicit complete support, even to the point that people are willing to die for them.

The very idea of a period like that known as the American Renaissance leads us to look for a unified set of ideas and aesthetic practices, which we come to think of as the ideology of the period. Writers can be arranged as expressing or dissenting from that ideology. Notions of ideology and dissent and of period identity and an authoritative discourse within each period are all interdependent. Once the concept of civil war as a normative situation within representation replaces that of ideology, this entire array of concepts falls away in tandem.

In literary studies of recent years what has been called the new historicism has, as a result of the strong influence of Foucault and the modern experience of totalitarianism and its analysis by Hannah Arendt and Max Horkheimer, among others, focused on the fate of representation within absolutist states or societies. The English Renaissance, taken as a glorious period of monarchy along with its secondary pressures and exceptions, became the natural topic for new historicist demonstrations.

The condition of civil war can be taken as the fundamental alternative to the condition of monarchical power, self-display, uniform discourse, ideology, and controlled representation. American new historicism has its basis in the representational situation not of monarchy but of civil war. To see the central episode of American history as the Civil War is to bring to the front the power of rhetorics, incomplete dominance of representation, and the borrowing or fusing of successful formulas of representation. Civil wars between contemporaries are only a local version of what, to use an Emersonian formulation, should be seen as the 
fundamental, permanent civil war in any society that is, like the United States, an economy rather than a culture. That underlying, permanent civil war, as Emerson described it in his essay on Napoleon, is between the young and the old, between power that represents work done in the past and the effort of the young to displace all that is being defended in order to make room for themselves in the world. Railroads overthrew canals and water-based transportation, and no sooner had they succeeded than the passenger automobile and long-distance truck overthrew the railroad. No sooner did Western Union have a monopoly on longdistance communication than the new telephone industry appeared to make that monopoly worthless.

The representational topic of monarchy is the inheritance, diffusion, and protection of power already held. The topic of civil war is an unstable contest for short-term control that is uninheritable and in the end, indefensible. Power is not the topic of this historicism, but its weak long-term expectations within a culture where economic power is not located in land, that one genuinely scarce, readily transferable, and not easily variable basis of power.

Of the essays in this collection more than half examine alternative rhetorics within the public sphere of the mid-nineteenth-century experience of the war over slavery, its abolitionist foreground, and its reconstructionist and New South aftermath. In the photographic images of the war itself Alan Trachtenberg reads the rhetoric of representation as it appeared within the camera, which, like the machine gun, was one of the new instruments of the war. The very existence of war photographs for the first time, alongside day-by-day newspaper reporting from the battlefield, set up a contest for the control and definition of this new visual genre.

Thirty years after the war, the rhetoric that Eric J. Sundquist sees consolidated in the Supreme Court's Plessy decision exists over against the liberal rhetoric of Reconstruction that it defeats by means not only legal and political but representational and scientific. The borrowed force of genetics, of the theories of degeneration, and of the successfully mythologized history of the South all become components of the consolidation both in the Plessy case and in Mark Twain's novel Pudd'nhead Wilson.

The reconstruction of imagery can clearly be seen between the Civil War photographs that are Alan Trachtenberg's concern, the photographs and drawings that are the topic of Henry Louis Gates's essay on the reconstruction of the image of the black, and, finally, the rhetoric of the first classic of the American film industry, Griffith's The Birth of a Nation, which Michael Rogin examines in his essay. That these two new representational forms, photograph and film, both situated themselves at once around the rhetorical struggles of the culture rather than around its celebratory myths is part of the evidence for the surplus of energy around discord within democratic cultures. 
In looking at the prewar period and its literature both Sacvan Bercovitch and Richard H. Brodhead locate a key transformation within rhetoric traceable to the unresolved history that would soon produce the war. Bercovitch traces the liberal political rhetoric of compromise to the historic Compromise of 1850 over slavery and to the anxiety over the European revolutions of 1848. This rhetoric of compromise becomes the foundation of a secular politics free of the vocabulary and rhetoric of the Puritan mission. That such a secular and liberal politics establishes itself as the successor to Puritan history Bercovitch brilliantly shows in his analysis of Hawthorne's Scarlet Letter. Brodhead traces the struggle in the same prewar years between two rhetorics of discipline, one strongly marked by the discipline of the whip within slavery, the other deriving from the tender domesticity of family life. The rhetoric of disciplinary intimacy, as he calls it, defines educational theory, the personalization of power in the family, and the growing importance of the domestic and the sentimental as modes of thought with implications for all larger social questions.

The transfer of energy and ammunition from one moment of rhetoric to another is the subject of Karen Sánchez-Eppler's essay on abolitionism and feminism. Rhetorics are borrowed or transferred, or they are composed into genial or unlikely hybrids. The interplay of rhetorics of seduction and genteel philanthropy and the emergence of a hybrid energy that is part of the cultural force of the Horatio Alger myth are the topics of Michael Moon's essay on the Horatio Alger stories.

The heart of this collection of essays is the central problem of the mutual projection of white and black identity as an ongoing, ever-reconstructed cultural matter. All other cultural matters imitate the dynamic of this fated American problem of representation. Each culture has its central problem within representation. For English culture that problem was and remains one of class. The features of this representational crux are borrowed, granulated, reassembled, reused, and copied until they appear in variant or disguised forms throughout the culture. In her essay Karen Sánchez-Eppler demonstrates the transfer of the structure of racial representation to American feminism, a feminism that inevitably exists in the aftermath of abolitionist energy whether in the nineteenth century or in the 1960s when a particularly effective feminist generation followed in the wake of a strong civil rights movement. Michael Moon's essay on class and homosexual-heterosexual constructions carries over the mechanisms crafted within the racial sphere into the economic and the sexual.

This topic gives a model for the strong hold of a democratic system of representation on works of high culture. So active, persistent, and even violent is the multiplication of images around a social fact like that of race that the capacity of Melville, Stowe, Twain, or Griffiths to work outside or even to modify the everyday cultural work of newspapers, jokes, legal argument and decisions, and 
political or social description of all kinds is limited in a unique way. The constraint on representation by ordinary culture is one of the clear results within the new American studies.

\section{Print Culture without the State}

The ordinary culture within which classic American authors and painters have worked has to be called a print culture, but now understood in a wider sense than the culture of the printed book. A photograph is also called a print, as is the copy of a film. Newspapers and journals, advertisements and billboards are also, in this sense, prints, offprints, and reprints. In the first essay of this collection Michael Warner sets out the model of the printer Benjamin Franklin with his new-made career within print culture, a culture replacing the oral culture of sermons, oratory, and statements linked to the personal presence of the speaker and the speaker's identification with his or her words. After Franklin all American authors, photographers, and filmmakers are printers.

The insertion of women into this ongoing authorial role and the replacement of the rhetoric of the lady novelist with a new self-representation is the subject that Elaine Showalter examines in the case of America's first successful highcultural woman novelist, Edith Wharton. Writing in 1905, Wharton appeared in the wake of a century of male novelists stretching from Cooper through Hawthorne, Melville, Howells, Twain, and James who had successfully made themselves into what the Victorians called classics. She also wrote her way out of the model of the lady novelist, the genteel or moral female scribbler, the type of popular writer whose presence and success had created a counter-tradition to the classic American literature that D. H. Lawrence described in 1920.

Both Warner and Showalter picture their author on the borderland between rhetorics of self-representation; at the same time each takes this writer as a model or pioneer within a general cultural shift. In Franklin's case the shift is from norms of oral culture to norms of rationality and print culture, with the new possibility to exploit self-separation, deception, and self-fabrication once the person and the word do not appear together in social space.

Franklin and Wharton individually invent and embody new cultural roles: a unique personal achievement seems to capture and direct the wider culture. In the essays by Sacvan Bercovitch and Eric J. Sundquist we see the opposite process: Hawthorne and Twain receive and condense cultural models that surround them, models that outweigh the individual work and saturate it from without.

As pairs of essays, the Franklin and Wharton on the one side and the Hawthorne and Twain on the other can be taken as contrasting examples of causation in literary studies, opposite explanations of the direction along which energy flows within culture. To see Franklin or Wharton as a pioneer in whose career a 
larger cultural shift can be observed is to credit the individual with the capacity to break the only existing model that she or he finds at his or her moment of cultural entrance. Energy and causation flow out from singular instances of success. In the studies of Hawthorne and Twain, however, it is the far more complex cultural strategies and the local combinations of the wider culture in its struggle to go on reformulating unanswered, never completely won or completely lost wars of representation that put before the artist a local habitation for his or her energy.

In this light my own essay on Whitman and Melville within the demands of a democratic social space describes the wider cultural collision between the project of democracy in aesthetics and in economics, the two realms where that project has been most necessary and most unlikely, and the fact of an already damaged social space. The strategies for satisfying the aesthetic project, on the one hand, and for dealing with the already damaged social space are at one level just the rhetorical inventions or preoccupations of Whitman or Melville. But they exist as outcomes of the larger cultural pressure and requirement and, at the same time, within the limits of the specific resources of that culture. In my reading those resources were always richest and most democratic on the economic plane.

The individual author is replaced as the object of attention in the essays by Richard H. Brodhead on disciplinary intimacy and Walter Benn Michaels on the outcome, in the works of a cluster of authors, of the interlaced rhetorics of individualism and machine industrial processes at the end of the nineteenth century. Michaels's topic is the fusion of what would seem at first opposite vocabularies of standardization and individualism, machine and self. His analysis captures a moment of oxymoron within naturalism, and also within American educational thinking and factory organization. Brodhead describes a cultural break between one disciplinary system and the new system of affective disciplinary intimacy and its outcome in a set of mid-century novels.

At the larger level of rhetoric, Brodhead's history by succession and Michael's history by superimposition set in front of us the two basic models for new historicism: transition and paradox. Of the essays that deal explicitly with two rhetorics, those by Michael Warner, Elaine Showalter, Richard Brodhead, Karen SánchezEppler, Eric Sundquist, and Henry Louis Gates, Jr., set in front of us the replacement of one rhetoric by another. The essays by Sacvan Bercovitch, Sharon Cameron, Philip Fisher, Michael Moon, Alan Trachtenberg, and Walter Benn Michaels confront us with the paradoxical side-by-side relation between strategies that we would expect to see only in conflict and opposition. One important claim being made by this latter group of essays is that opposition, resistance, and the sharpening of representations so that we can face such choices as those between subversion and collusion, opposition and participation, and victory and defeat are less significant goals within representation than we usually imagine. Fusion, compounding, and the delay or evasion of choice are often the marks of a latent 
civil war. This is clear in Walter Benn Michaels's essay, where we would expect the combination of the factory system in a culture of individualism, the moment of unions and bosses in America, and the aggressive methods of literary naturalism to work together to moralize the late nineteenth-century situation, and to do so by sharpening differences into opposites that invite choice and by promoting consciousness, whether class consciousness or simply consciousness at large. Instead we find a systemic blending, an avoidance of transition from one coherent model to another. We find ourselves with a picture of a culture living on in spite of the requirements of facing up to its contradictions and improvisations, a culture making successful, short-term use of opposites precisely because it has no interest in finding its way to any long-term, stable, integrated identity or ideology.

The essays in this collection center on nineteenth-century American texts, and they do so for a reason. These texts have always been the battleground where shifts in national self-conception and the accompanying shifts in the cultural projects of a generation are fought out. The cultural facts that we renovate, filter out, discard, or rediscover are among the most highly visible clues to what we imagine ourselves to be. The past of yesterday is not necessarily our past.

No figure has been reargued as often as Emerson, and yet the central part of Emerson, or some one of the many different accounts of Emerson, is again prominent in the recent reworking of the past. The Emerson of Sharon Cameron's essay is a figure of paradox, a man whose discovery of the thin hold of grief over his imagination, even the grief over his dead child, has given him a pattern for the nature of experience in general and a triumphant affirmation based on what might seem to be his own callousness. From Emerson's consciousness of what we could call not his refusal to mourn but his failure to mourn he passes to the knowledge that experience itself is in its nature dissociated, and further, that an ever-mobile present anchors us in spite of the intense claims of the past, even when that past is the recent loss of a child. Cameron's reading of the clash between the rhetoric of grief and the rhetoric of experience has its strongest evidence in the very dissociation of Emerson's own aphoristic style. Stronger than that dissociation, however brave or reckless, is the collapse of one rhetoric into another as in the startling sentences: "We thrive by casualties. Our chief experiences have been casual." In this wordplay on the accidental, the injurious, and the shallow that Cameron isolates in the essay "Experience," Emerson packs the bitter knowledge of a set of puns like those in Shakespeare's A Winter's Tale but without its darkness. Here the feckless is raised to the philosophical.

The strong outcome of deconstructive readings can be seen in the layering of language in Cameron's reading of Emerson, Bercovitch's of Hawthorne, my own of Melville, and Michaels's of the cultural languages of individualism and standardization. Syntax gets particular attention here as a level where the undecided can be stabilized, but not resolved, as in the many either/or structures in Melville. In Bercovitch's essay it is Hawthorne's structures of negation that accom- 
plish this syntactic work. Deconstruction's most enduring outcome has been its powerful analytic techniques in the face of brief crux passages. In this respect, deconstruction extended but did not reverse the techniques of close reading that dominated literary study in the 1950s. Ultimately, deconstructive analysis was rhetorical; it was an analysis of tropes and layers within representation. The historicizing of this rhetorical analysis can be seen in the rapid sketch of Emerson that appears in one of Bercovitch's notes: "Emersonian troping is nothing less than a transvaluation of the entire process of westwarding into an interior process of vision that re-presents America as potential. In effect, Emerson marshals the rhetoric of progress against imperialism; self-possession against possessive individualism; transition against upward mobility; marginality against the facts of the frontier; speculation against the marketplace; and summarily 'America' against the United States. This is adversarial rhetoric but also an example par excellence of cultural counterdependence." In this brilliant passage setting rhetoric against rhetoric the deconstructive and the historical are perfectly fused.

Unlike myths, which take on all possible historical circumstances as illustrations and by this means become universal explanations, rhetorical analysis is never universal. One important reason for the local nature of the analysis of rhetorics found in these essays is the lack of what might be called, in the European sense, the state in American experience and therefore the absence of any monopoly of either power or violence on the part of the state. Centralization of power on the European model, and with it the centralization of the power of representation and self-conception as it has been described by Foucault, was never present in America. Even outside the arena of cultural conflict, or civil war per se, the culture provided the richest possible resources for escape, invisibility, and defiance. The right to "move on" or "head out west" was only one of these possibilities that limited the creation of a state. More important was the economic commitment to a rapidly changing culture of invention, with its dizzy cycles of the amassing, loss, and transfer of wealth and power. This economic commitment was far more decisive than the purely individual right to escape or move on, but even that apparently individual mobility was historically profound because it was the means of renewing the act of immigration-leaving behind and moving onwhich was each individual's first drop of American identity.

In fact, such an economic pressure is a form of willed, collective instability because it accepts the future as an already bankable asset that can be borrowed against to speed up the overthrow of the past. In a speculative culture, the profits of the railroads fall into an investment pool, where, because they are in search of the highest returns, they are not reinvested in the railroad system itself but rather in the emerging automobile industry whose only purpose is to overthrow the railroads as the fundamental transportation system. By means of the speculative system the past becomes the silent partner of the future that will abolish its own hold. A culture of speculation is opposite in its action to those cultures of pres- 
ervation, inheritance, and self-reproduction that we tend to take anthropologically as the human norm. Pierre Bourdieu's Outline of a Theory of Practice, precisely because it is concerned with societies whose primary goal is reproduction in the widest sense of self-replication and continuation as is over time, can never describe an Emersonian or speculative society whose commitment to selfdestruction in the name of its own next possibility is far more important than its interest in the transfer of the forms of the past to a future generation.

For these reasons, analysis within American studies will always be of sectors of a diverse culture characterized by the absence of a monopoly of power. These studies will always be historical and not anthropological because of the commitment of the culture itself to a rapid building up, wearing out, and replacement of systems of all kinds by new arrays of persons and forces. The updraft is strong, the door of immigration both to and within the country is open, the exhaustion of control is always imminent, and control itself is porous. Because America had no experience of monarchy, it has a permanent democratic core working not only against the centralization of power but, more important, against its inheritance or preservation over time.

In the absence of a state we find ourselves freed of the intellectual component of the systematic state: ideology. We have rhetorics because we have no ideology, and we have no ideology because we lack the apparatus of ideology: a national religion, a unitary system of education under the control of the state, a cultural life and media monopolized by the state by means of either ownership or subsidy. Ideology is a cultural mechanism of stabilization and transmission, neither of which is a primary topic of a culture of speculation.

The study of rhetorics is our necessary alternative to the study of ideology. Rhetorics are the sign of the play of forces within cultural life and at the same time of the power of invention and obsolescence within culture. Rhetoric is the mark of temporary location and justification. The nuances of provisional justification and defense, the opening up of newness within culture without escaping the grip of the master problems and resources of the culture: this is what is at issue in the essays that follow. 